\title{
The Biological and Social Determination of Man's Psychic Development
}

\author{
Fang Wang \\ College of Foreign Languages, Changchun University of Science and Technology, Changchun, China \\ Email: harmonywang@163.com
}

Received 3 November 2014; revised 3 December 2014; accepted 10 December 2014

Copyright (C) 2014 by author and Scientific Research Publishing Inc.

This work is licensed under the Creative Commons Attribution International License (CC BY). http://creativecommons.org/licenses/by/4.0/

c) (i) Open Access

\begin{abstract}
Throughout the history of education research, certain views were expressed which considered that the main determining force in an individual's personality development was the biological factor. On the other hand, there were other experts who underestimated the biological factor and concentrated on the social factor. The struggle between these contradictory views was of long duration. In this article, the author tries to discuss about both the biological determination of personality development and the training of man, and the influence of the social environment on personality development and the training of man.
\end{abstract}

\section{Keywords}

Biological Determination, Social Environment, Heredity, Education, Psychic Development

\section{Introduction}

The educator (in the broadest sense of the word) is responsible for personality development and the purposeful training of children, young people and adults [1].

As a rule, teachers and educators have already undergone university education. Nevertheless, in practice they are often faced with some basic issues to be solved in the process of education and upbringing. These are as follows: Are parents, teachers and educators capable of training the personalities of children and young people in accordance with social requirements and their own qualifications? Does education play any role in this training or is the individual's future predetermined by hereditary factors? Are we then helpless against these hereditary factors? These are the questions raised not only by the theory, but, first and foremost, by the practice of education.

The issues of people's psychic development are explored by individual psychological disciplines from different aspects. They are studied by educational psychology, the purpose of which is to investigate, discover and 
explain the psychological foundations of the process of education and upbringing. Educational psychology examines these issues particularly from the point of view of the psychological foundations of the purposeful, intentional and planned development of man. Our starting point suggests the notion that only knowledge about the substance of these issues will provide the scientific basis for influencing man's education and behavioural patterns [2].

\section{The Biological Determination of Personality Development and the Training of Man}

In the past, certain views were expressed which considered that the main determining force in an individual's personality development was the biological factor. These views underestimated environmental factors, especially the social one. On the other hand, there were other authors who underestimated the biological factor and concentrated on the social factor-often thought to be constant—as the only determining force in man's psychic development. The struggle between these contradictory views was of long duration.

The biological determinants of man's psychic development include: the activity and characteristics of the nervous system and the sensory organs; the activity of the endocrine glands; the growth of the organism; the overall and momentary physical state; biological needs and instincts; heredity; innateness; and certain defects and diseases.

Disagreements between psychologists were focused mostly on questions of heredity, or its influence on the development and formation of man's psyche.

Under the term "heredity", we understand the tendency of an organism to preserve and to transmit the parents' features and characteristics to posterity.

The first expert in the field of heredity is considered to be the cousin of C.R. Darwin—f. Galton (1822-1911), who in 1869 published the book hereditary genius, very often quoted in this sphere.

Galton postulated two laws concerning heredity among people:

1) The law of filial regression (parents of above-average height have smaller children and parents of belowaverage height have taller children). This represents a regression to average.

2) The law of the hereditary share of ancestors (children inherit one-half of their characteristics from their parents, one-quarter of their characteristics from their grandparents, one-eight from their great grandparents, etc.).

We are interested in questions of heredity concerning psychic characteristics. Galton even investigated these issues, namely questions involving the inheritance of abilities and talent. He presumed that famous people were also extraordinarily capable and gifted, and that their outstanding abilities were inherited. He identified talent with social status. He alleged that life in society is similar to life in nature in that only individuals with outstanding abilities break through and succeed, in spite of the obstacles.

Galton's theory was criticized by one of the founders of Soviet psychology, M. B. Teplov [3], who pointed out methodological errors and shortcomings that led to incorrect conclusions. Teplov held a similar viewpoint to the research of K. Cox and L. M. Terman.

Cox, under the leadership of Terman, undertook to find out from what kind of families (occupation of the father) the most famous historical figures came from between 1450 and 1850. She selected the most famous people from Cassell's dictionary. She excluded all persons with insufficient biographical data, as well as sovereigns and the established aristocracy, who inherited their ranks. She ended up with 282 famous men. According to the occupation of their fathers, they came from the following social groups: the fathers of $52.5 \%$ of famous men were noblemen and intellectuals; $28.7 \%$ were semi-intellectuals, tradesmen and independent farmers; $13.1 \%$ were skilled workers and retailers; $3.9 \%$ were semi-skilled workers; and $0.7 \%$ was unskilled workers [4].

Teplov criticized the selection of the famous people in this 400-year span, as well as their order in Cox's list. It is strange that E. Burke, an activist in the British political party called the Whigs (later the Conservative Party) appeared in sixth position, while such great names as Darwin, Beethoven, Kopernik and Bach occupied 68th, 121st, 192nd and 269th positions respectively! [5]

L.M. Terman [6] lived in the United States where there were no royal or aristocratic families. He also investigated the social origin (occupation of the father) of gifted children. After detailed testing, the following findings were obtained: the fathers of $31.5 \%$ of the best pupils were intellectuals; $50.0 \%$ semi-intellectuals and tradesmen; $11.8 \%$ skilled workers; $6.6 \%$ semi-skilled workers; and $0.13 \%$ unskilled workers. 
Another author who approached the question of heredity through the investigation of pedigrees was H.N. Goddard. In one town it was noticed that some low-class and anti-social inhabitants had the same surnames as some families of high repute. After studying their pedigrees, he found that both groups had a common ancestor (Goddard gave him the nickname Martin kallikak from the Greek kaloc = "good" and kakos = "bad"), who on the basis of the recorded data had been on terms of intimacy with a mentally-retarded woman. They had a son who was equally mentally retarded, but had many investigated. Goddard investigated 480 of them and found out that only forty-six of them were mentally normal, 143 were mentally retarded and the others had questionable intelligence. Among the group of sub-normal individuals were twenty-four notorious alcoholics, thirty-five sexual deviants and three convicted criminals. The report on Goddard's research was presented by S. S. Sargent [7].

Later on, Martin Kallikak married a mentally normal woman. This union resulted in 496 descendants and, with the exception of three persons, they were all mentally and socially normal. Goddard came to the conclusion that the degeneration of the first group was due to the hereditary influence of the mentally-retarded mother. He did not take the influence of bad environment into consideration for the first group and the influence of the environment enjoyed by the descendants of the second group.

Another sphere of research on hereditary influence concerning the development of man's psyche is represented by studies on identical twins, i.e. born from one fertilized ovum. Identical twins have the same hereditary skills.

In connection with the heredity of intelligence, the relation (correlation $=r$ ) between the intelligence quotients (IQ) of parents and children, and between the siblings to one another were investigated. The following findings were obtained: between parents and children $r=0.58$; between siblings of various ages $r=0.53$; between binovular twins $r=0.63$; and between identical twins $r=0.88$.

These correlations are high. One could ask if this is the result of heredity, or if it is influenced by the family environment. Research conducted so far suggests that monozygotic (identical) twins are more alike in their intelligence than the ordinary (dizygotic) twins, which tends to support the influence of hereditary factors. In other studies, it was shown that if the identical twins did not live in the same environment their IQ correlation coefficient was 1.77.

Human genetics is still faced by many unknowns. The relationship between inherited and inborn intelligence and acquired intelligence will be dealt with in more detail in another part of this work. However, one point seems to be certain: the link is not straightforward, and only hereditary information (genes) is transmitted directly. All the important chemical, structural and functional traits of the organism are to a certain degree dependent on genes. The genes located in the chromozomes of the cellular nucleus represent the developmental programme of the organism, deposited in the molecule of desoxyribonucleic acid. It is acknowledged that this acid forms the material basis, i.e. the genetic starting-point, of development.

The development of man does not start at the time of his birth, but at the moment of conjugation of the ovum and the sperm, with fertilization. A zygote is formed, the starting-point of development. The zygote contains hereditary information, yet it is liable to the influence of its environment. Intra-uterine development of the foetus is then influenced not only by the hereditary characteristics of parents and ancestors, but also by the influence of the mother's body.

What is then inherited? It is rather difficult to answer this question, because after birth the child brings to the world not only hereditary traits, but also those acquired during the development of the foetus in the mother's body. Therefore we cannot identify hereditary traits with inborn traits. The term innateness is of broader significance than the term heredity. The inborn traits include hereditary skills, as well as the traits and signs that originated during the development of the foetus in the uterus.

It cannot be denied that the general signs of species and races are inherited. From embryonic cells of man only people arise; from the embryonic cells of white men, white men and women are born; and from embryonic cells of black races, black men and women are always born. The blood group is also inherited. Certain physical and mental diseases are inherited as well, e.g. haemophilia (improper clotting of the blood that may cause bleeding to death). This fact was known already to ancient Jews and therefore the Talmud (the Jewish religious code) forbade the circumcision of new-born boys when the brother or the uncle of the mother suffered from haemophilia. Some forms of lip and palate fissures are also inherited. Among mental defects are, for example, the oligophrenic states (debility, imbecility and idiocy).

The new-born child inherits from its ancestors certain anatomical-physiological characteristics or skills that 
make it possible to form its psyche. Here lies the multi-potentiality for personality development. It is generally known that at birth man is the most helpless of all creatures on earth. No other animal is dependent so much and for so long on the care of adults (parents or foster-parents) as man, but no other animal has such potential for development as man. Even the inherited characteristics make men different from other animals, which creates the possibility for men to be trained, to behave and to be educated in accordance with the objectives of society.

Certain biological determinants of the psychic development of man are also transmitted hereditarily. Among others, they include the following: specific human traits of physical organization, especially the structure of the brain, its architectonics, the specific fields of the cortex of large hemispheres, the special structure of analysers, the functional properties of the nervous system, especially its unusual plasticity, making it possible to form innumerable new and complex temporary neural connections and to reflect the surrounding world in all its complexity. Hereditary character includes the primary biological functions associated with the instinctive reflex movements. On the basis of these needs, new secondary needs may arise, historically, in the process of human development, as well as the possibility of evolving new forms of activity and various psychic characteristics.

Inherited characteristics have an inevitable influence on an individual's psychic development. Similarly, as with plants and sub-human animals, the hereditary factors for man have great significance. With plants and animals these factors are often the decisive ones for development. With man it is different. What we inherit from our parents and ancestors are just potentials for the development of our psyche; they are not ready-made psychic traits.

In concluding, our discussion on the biological determination of man's psychic development (especially the influence of heredity), it is necessary to mention the fact that the exact degree of influence of hereditary factors on personality development is still unknown. One of the principal tasks of human genetics is to make this problem clear.

\section{The Influence of the Social Environment on Personality Development and the Training of Man}

The following statement by the American psychologist and behaviourist J. B. Watson to the effect is often quoted Give me a doyen healthy, shapely children and a specific world in which to educate them and I can guarantee that I shall make any of them a specialist to my own choice: physician, lawyer, artist, successful businessman, or even beggar and thief, without respect to his gifts, tendencies, interests and the race of his ancestors.

This statement clearly indicates an overestimation of the environmental influence and an underestimation or denunciation of biological factors in the development of man's psyche.

Views overestimating the influence of the environment are rooted in the attitude of the preceding centuries. Most of all they are influenced by the ideas and statements of John Locke (1632-1704), the culminator of Bacon's empiricism who, in his Essay on human understanding, demonstrated that the mind of a new-born man is like that of a blank tablet (tabula rasa).

The above views and the ones derived from them represent the extremes, denying the mutual interaction of organism and environment. They consider the environment as something constant, independent of men, affecting the psyche automatically, by its very existence, without man being able to react.

The social determination of development in man's psyche represents the most natural human determination. Without other people, man would not be able to become a person in the proper sense of the word. As evidence, we can refer to cases where young children were, due to some accidental circumstance, left without human company, as "jungle babies". The child needs the company of other people, of adults; otherwise, he/she will not even be able to learn to speak, since speech is acquired on the basis of imitation. Social activities are inevitable for the development of man's psyche. The influence of the social environment on man's psyche is not, however, a mechanical, self-redeemable and overwhelming influence. Social influence would count for little if it were not realized in active co-operation with the developing individual. Here we are face to face with the dialectical principle of the unity of organism and environment.

The social determination of development and formation on man's psyche includes the following factors: social customs, ethical norms, laws, taboos, human activity, etc. However, their influence is not always organized, appropriate or desirable. Therefore, these kinds of social determinants are referred to as elemental influences. In spite of this, there is one social determinant for the development of man's psyche which represents a purposeful, planned and systematic influence. This social factor is called "education" and the environment in which it is rea- 
lized is called the "educational environment".

It may be deduced from the diagram that at the beginning and at the end of ontogenesis the factors of heredity dominate environmental factors. It is bicategorial, that is, a biological-social model.

The extreme representatives of heredity considered hereditary factors to be decisive determinants in the development of man's psyche, while the extreme representatives of the environment claimed that only the environment determined the development of man's psyche. The evolution of scientific thought has confirmed that both of these views are untenable. Aware of this, the German psychologist W. Stern (1871-1938) [7] attempted a kind of synthesis between these two theories in the form of the so-called "theory of convergency". According to Stern, personality is the result of inborn and acquired traits. In describing this theory G. Clauss and H. Hiebsch stressed that it was based on the so-called parallelogram of powers, based on the model of mechanics, according to which the resultant of two sets of powers is a certain effect. They go on to argue:

This initial clear conception is, however, a mechanical one and therefore false. The conception that hereditary gifts or environmental influences (either educational measures or activity) are forces that act upon the object simultaneously, i.e. the child, from the outside, thus developing its abilities and traits, is untenable. Such a theory considers the child only as an object or a puppet affected by different forces, while in fact the child is the subject of its own development [8].

Nowadays the view is held that, with the help of adults, the developing child is a joint creator of its own personality, respecting hereditary and inborn characteristics. By its own activity (play, learning and work) the developing child regulates its own development, its own behaviour in individual stages of ontogenetic development. Therefore, besides the biological and social determination of development in man's psyche, we should also include the psychic regulation of behaviour, i.e. the self-formation of an individual's personality.

We should mention in this connection the words by A. N. Leontiev [9] which stressed that the foundations of man's personality do not represent his genetic dispositions and destiny, acquired habits, knowledge and capabilities, but the system of activities realized as a result of this knowledge and these capabilities.

\section{References}

[1] Scott, M.H. and Duane, F.A. (2008) Handbook of Cognitive Aging: Interdisciplinary Perspectives. Sage Publications, Thousand Oaks.

[2] Kozulin, A. (2002) Psychological Tools: A Sociocultural Approach to Education. Harvard University Press, Cambridge.

[3] Tenlov, B.M. and Schopnosti, A. (1980) Abilities and Talent. SPN, Praha, 51.

[4] Terman, L.M., et al. (1926) Mental and Physical Traits of a Thousand Gifted Children. 2nd Edition, Stanford University Press. Stanford. (Genetic Studies of Genius, Vol. 1).

[5] Sargent, S.S. (1947) Základypsychologie (Essentials of Psychology). ziivot a práce, Praha.

[6] Švancara, I. (1982) Interaction of Docial and Biological Determination in the Development and Forming of the Personality. Sborníkprací Filozofickéfakulty Brnenské University, I, Radapedagogicko-psychologicka (Brno), roĉ, 17, 3749.

[7] Stern, W. (1928) Die Intelligenz der Kinder und Jugendlichen und die Methodenihrer Untersuchung (Intelligence of Children and Youth and Its Research Methods). 4th Edition, Leipzig.

[8] Clauss, G. and Hiebsch, H. (1970) Psychológiadetstva a dospievania. (Psychology of Children and Maturation). SPN, Bratislava, 57.

[9] Leontiev, A.N. (1978) Činnost, vědomi, osobnost. (Activity, Consciousness, Personality). Svoboda, Praha. 
Scientific Research Publishing (SCIRP) is one of the largest Open Access journal publishers. It is currently publishing more than 200 open access, online, peer-reviewed journals covering a wide range of academic disciplines. SCIRP serves the worldwide academic communities and contributes to the progress and application of science with its publication.

Other selected journals from SCIRP are listed as below. Submit your manuscript to us via either submit@scirp.org or Online Submission Portal.
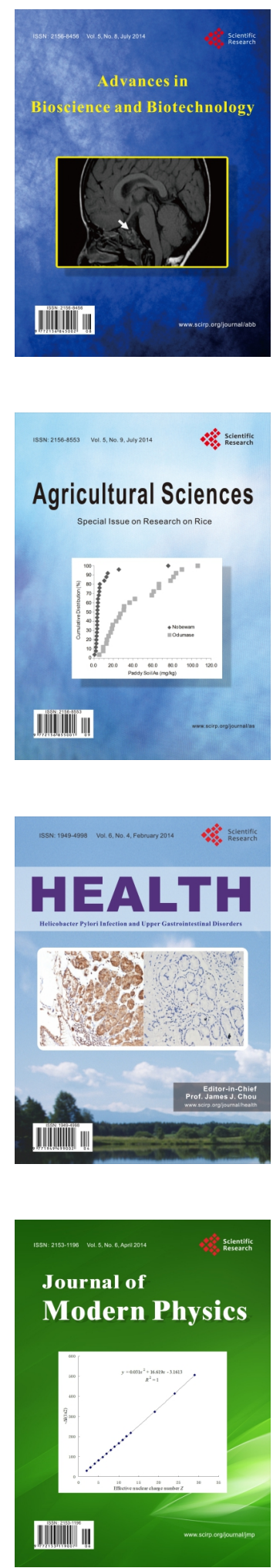
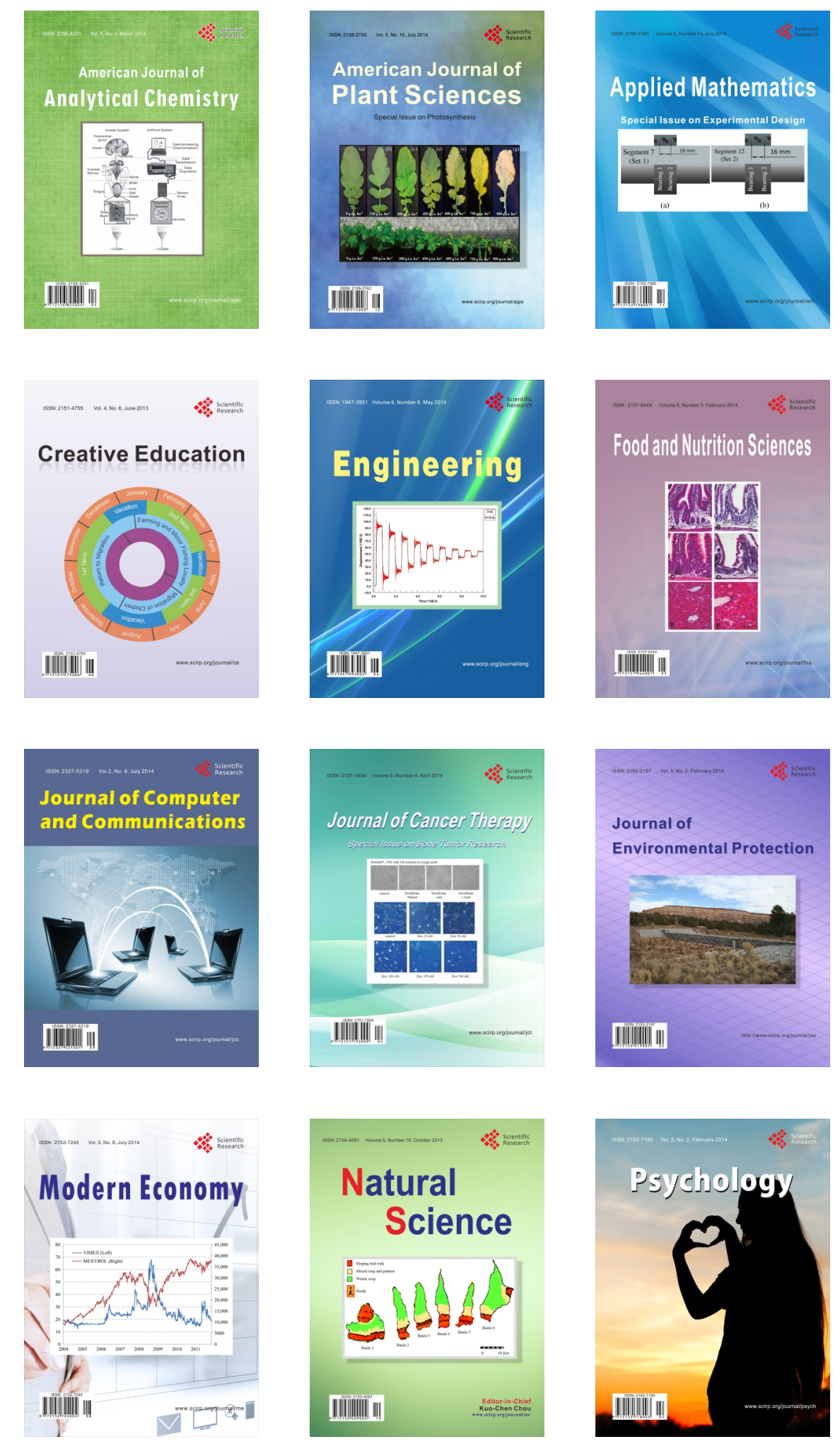